\title{
Bifidobacterium animalis (Mitsuoka) comb. nov. and the "minimum" and "subtile" Groups of New Bifidobacteria Found in Sewage
}

\author{
V. SCARDOVI and L. D. TROVATELLI
}

Istituto di Microbiologia Agraria, Università di Bologna, Bologna, Italy

\begin{abstract}
Twenty-two strains of bifidobacteria from the feces of chickens, rats, and rabbits, and from sewage, formed a single deoxyribonucleic acid (DNA) homology group displaying complete homology with Bifidobacterium longum subsp. animalis Mitsuoka biotype $a$ strain R101-8 (=ATCC 25527). The DNA relatedness of this group of strains to the known species of the genus Bifidobacterium ranged from 5 to $40 \%$. Therefore, we propose that B. longum Reuter subsp. animalis Mitsuoka biotype $a$ should be elevated to species rank as Bifidobacterium animalis (Mitsuoka) comb. nov. The type strain is ATCC 25527. Also, a small number of strains isolated from sewage are suggested as probably being distinctive bifidobacteria and are placed in two new groups designated "minimum" and "subtile." The reference strains for these groups are F392 (=ATCC 27538) and F395 (=A TCC 27537), respectively.
\end{abstract}

Mitsuoka (2) proposed the names Bifidobacterium thermophilum, Bifidobacterium pseudolongum, and Bifidobacterium longum subsp. animalis for bifidobacteria he isolated from the feces of various animals, such as pigs, chickens, rats, and guinea pigs. Bifidobacterium ruminale and Bifidobacterium globosum were isolated in our laboratory from the rumens of cattle $(8) ; B$. ruminale subsequently (9) proved to be identical with $B$. thermophilum Mitsuoka, and $B$. globosum was closely related (9) to $B$. pseudolongum Mitsuoka as demonstrated by deoxyribonucleic acid (DNA)-DNA hybridizations. The question of the identities of $B$. pseudolongum and $B$. globosum was left open because of some differences in the guanine plus cytosine $(\mathrm{G}+\mathrm{C})$ contents of their DNAs: in $B$. pseudolongum the $\mathrm{mol} \% \mathrm{G}+\mathrm{C}$ is $60.1 \pm 0.4$, and in $B$. globosum it was $63.8 \pm 0.4(8)$. In the meantime, Matteuzzi et al. (1) isolated from pig feces a new species, Bifidobacterium suis, whose DNA homology relations and phenotypic characteristics are distinctive among the bifidobacteria.

In DNA homology experiments (9), Mitsuoka's biotypes $a$ and $b$ of $B$. longum subsp. animalis were found to be unrelated to $B$. longum Reuter. Furthermore, strain R101-8 (=ATCC 25527), representative of $B$. longum subsp. animalis biotype $a$, could not be assigned to any known species of Bifidobacterium, and strain $\mathrm{C} 10-45$, representative of $B$. longum subsp. animalis biotype $b$, was found to be related to $B$. pseudolongum. Among a large number of bifidobacteria isolated from the feces of chickens, rats, and rabbits, and from sewage, we found 22 strains whose DNA exhibited little or no relatedness to the DNAs of known species of Bifidobacterium. The purpose of this study is to determine the taxonomic position of these strains and that of $B$. longum subsp. animalis biotype $a$.

\section{MATERIALS AND METHODS}

Bacterial strains. The strains included in this study are listed in Table 1. All of the strains were studied for their DNA relatedness to the reference strains of the various Bifidobacterium species listed in Table 1.

DNA-DNA hybridization. The procedures used for determining DNA relatedness were performed as previously described $(5,9)$.

Determination of phenotypic characters. The methods used to determine the phenotypic characters of the strains studied were also previously described (5).

\section{RESULTS}

DNA homology relationships. The data in Table 2 show how closely the animalis group is related to reference strain $\mathrm{P} 23$-homology val- 
TABLE 1. Strains used

\begin{tabular}{|c|c|c|}
\hline Organisms & Isolated from & $\begin{array}{l}\text { Culture received } \\
\text { from }\end{array}$ \\
\hline \multicolumn{3}{|l|}{$\begin{array}{l}\text { Bifidobacterium animalis (Mitsuoka) comb. nov. } \\
\text { R101-8 (B. longum subsp. animalis biotype } a \text {, Mitsuoka (2)) }\end{array}$} \\
\hline $\begin{array}{l}\text { R101-8 }(\text { B. longum subsp. animalis biotype } a, \text { Mitsuoka }(2)) \\
(=\text { ATCC } 25527) \ldots \ldots \ldots \ldots \ldots \ldots \ldots \ldots \ldots \ldots \ldots \ldots \ldots \ldots \ldots \ldots \ldots\end{array}$ & Feces of rat & T. Mitsuoka \\
\hline $\mathrm{P} 16 ; \mathrm{P} 17 ; \mathrm{P} 23 ; \mathrm{P} 26 ; \mathrm{P} 32 ; \mathrm{P} 39 ; \mathrm{P} 45 \ldots \ldots \ldots \ldots \ldots$ & Feces of chicken & Our collection \\
\hline T6; T27; T98; T160; T169 & Feces of rat & Our collection \\
\hline RA12;RA13; RA14; RA15; RA16; RA18; RA20; RA23 & Feces of rabbit & Our collection \\
\hline 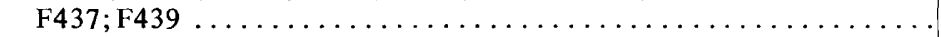 & Sewage & Our collection \\
\hline \multicolumn{3}{|l|}{ Subtile group } \\
\hline F395, reference strain; F340; F394; F396; F398 & Sewage & Our collection \\
\hline \multicolumn{3}{|l|}{ Minimum group } \\
\hline F392; F399 . & Sewage & Our collection \\
\hline Bifidobacterium bifidum (Tissier) Orla-Jensen S28a (=ATCC 15696) & Feces of infant & G. Reuter \\
\hline B. breve Reuter S1 (=ATCC 15700) Type strain (4) . . . . . . . . . & Feces of infant & G. Reuter \\
\hline B. liberorum Reuter S76e (=ATCC 15702) Type strain (4) & Feces of infant & G. Reuter \\
\hline B. adolescentis Reuter E298b (=ATCC 15705) biotype $c$ (3) & Feces of adult & G. Reuter \\
\hline B. longum Reuter E194b (=ATCC 15707) Type strain (4) . & Feces of adult & G. Reuter \\
\hline \multicolumn{3}{|l|}{ B. catenulatum Scardovi and Crociani B669 (=ATCC 27539) Type } \\
\hline$\ldots \ldots \ldots \ldots \ldots \ldots \ldots \ldots$ & Feces of adult & Our collection \\
\hline B. dentium Scardovi and Crociani B764 (=ATCC 27534) Type strain (5) . . & Dental caries & Our collection \\
\hline B. angulatum Scardovi and Crociani B677 (=ATCC 27535) Type strain (5) & Feces of adult & Our collection \\
\hline B. ruminale Scardovi et al. RU326 (=ATCC 25866) Type strain (8) & Rumen of cattle & Our collection \\
\hline B. globosum Scardovi et al. RU230 (=ATCC 25864) Type strain (8) & Rumen of cattle & Our collection \\
\hline B. suis Matteuzzi et al. SU859 (=ATCC 27533) Type strain (1) . . & Feces of pig & Our collection \\
\hline B. asteroides Scardovi and Trovatelli C51 (=ATCC 25910) Type strain (7) & Intestine of bee & Our collection \\
\hline B. indicum Scardovi and Trovatelli C410 (=ATCC 25912) Type strain (7) .. & Intestine of bee & Our collection \\
\hline $\begin{array}{l}\text { B. coryneforme Scardovi and Trovatell } \mathrm{C} 213(= \\
\text { strain }(7) \ldots \ldots \ldots \ldots \ldots \ldots \ldots \ldots \ldots \ldots \ldots\end{array}$ & Intestine of bee & Our collection \\
\hline
\end{tabular}

TABLE 2. DNA homology relationships between $B$. animalis and other species of the genus Bifidobacterium

\begin{tabular}{|c|c|}
\hline Competitor strains & $\begin{array}{l}\text { Reference strain } \\
\text { B. animalis } \mathrm{P} 23\end{array}$ \\
\hline P23 (=ATCC 27536) & 100 \\
\hline P16;P17;P26 ..... & $98-92-98$ \\
\hline P32; P39; P45 & $98-98-72$ \\
\hline Т6; Т27; Т98; Т160; T169 ...... & $.72-72-98-90-88$ \\
\hline F437; F439 & $90-85$ \\
\hline RA12; RA13; RA14;RA15 . . . . & . $85-85-92-94$ \\
\hline RA16; RA1 8 ; RA $20 ;$ RA2 $23 \ldots \ldots$. & . $90-86-90-86$ \\
\hline R101-8 $(=$ ATCC 25527$) \ldots \ldots \ldots$ & 99 \\
\hline Bifidobacterium bifidum S28a . . . . . & 10 \\
\hline B. liberorum $\mathrm{S} 76 \mathrm{e} \ldots \ldots \ldots$ & 15 \\
\hline$B$. breve $\mathrm{S} 1 \ldots \ldots \ldots \ldots \ldots$ & 22 \\
\hline B. adolescentis $\mathrm{E} 298 \mathrm{~b} \quad \ldots \ldots \ldots$ & 30 \\
\hline B. longum E194b . . . . . . . . . & 5 \\
\hline B. catenulatum B669 ......... & 8 \\
\hline B. dentium B764 ........... & 6 \\
\hline B. angulatum B677 . . . . . . . & 11 \\
\hline B. globosum RU230 . . . . . . . . & 40 \\
\hline B. ruminale RU326 & 23 \\
\hline minimum group F392 . . . . . . & 5 \\
\hline subtile group F395 . . . . . . . & 5 \\
\hline
\end{tabular}

ues ranged from 72 to $99 \%$. B. longum subsp. animalis biotype $a$ strain R101-8 (=ATCC 25527) displayed $99 \%$ homology to the same reference system. Undoubtedly these strains form a very homogeneous group. The DNAs from type strains of the known species of the genus Bifidobacterium and of reference strains of the "minimum" and "subtile" groups competed only slightly, if at all, in the homologous reference system P23; only B. globosum RU230 showed some $40 \%$ homology to this reference; thus, this result and the results of the reverse reactions (see Table 4) indicate a certain similarity of some regions of the genome of $B$. globosum and the "animalis" reference strain.

The results of similar competition experiments conducted with reference strains F392 (minimum group) and F395 (subtile group) are reported in Table 3. Only low levels of homology were demonstrated between the minimum and subtile groups, and, similarly, low or even zero levels of homology were found with DNA competitors covering all the specific taxa of the genus Bifidobacterium. Because of some morphological resemblance of the mini- 
TABLE 3. DNA homology relationships between the minimum and subtile groups and species of the genus Bifidobacterium

\begin{tabular}{|c|c|c|}
\hline \multirow[b]{2}{*}{ Competitor strains } & \multicolumn{2}{|c|}{ Reference strains } \\
\hline & $\begin{array}{l}\text { F392 } \\
\text { (Group } \\
\text { mini- } \\
\text { mum) }\end{array}$ & $\begin{array}{l}\text { F395 } \\
\text { (Group } \\
\text { subtile) }\end{array}$ \\
\hline minimum group & & \\
\hline F392; F399 . & $100-103$ & $16-20$ \\
\hline subtile group & & \\
\hline F340; F394; F395 & $10-20-31$ & $70-94-100$ \\
\hline F396;F398 $\ldots \ldots$ & $20-23$ & $70-80$ \\
\hline Bifidobacterium bifidum $\mathrm{S} 28 \mathrm{a}$ & 4 & 4 \\
\hline B. liberorum $\mathrm{S} 76 \mathrm{e} \ldots \ldots \ldots$ & 4 & 5 \\
\hline B. breve $\mathrm{S} 1$ & 10 & 17 \\
\hline B. adolescentis E298b ... & 5 & 13 \\
\hline B. longum E194b .... & 7 & 23 \\
\hline B. catenulatum B669 & 30 & 12 \\
\hline B. dentium B764 & 5 & 00 \\
\hline B. angulatum $\mathrm{B} 677$ & 23 & 8 \\
\hline B. globosum RU230 & 35 & 10 \\
\hline B. ruminale RU326.. & 4 & 15 \\
\hline B. suis SU859 ...... & 10 & 8 \\
\hline B. asteroides C51 . . & 00 & 2 \\
\hline B. indicum $\mathrm{C} 410 \ldots$ & 00 & 00 \\
\hline$B$. coryneforme $\mathrm{C} 215$ & 4 & 00 \\
\hline B. animalis $\mathrm{P} 23 \ldots \ldots$ & 5 & 10 \\
\hline
\end{tabular}

mum strains with $B$. indicum from the intestine of the bee (7), preparations of DNA from the type strain of $B$. indicum, ATCC 25912, were included; they proved absolutely unrelated to both reference systems (minimum and subtile). In the experiments reported in Table 4, DNA-DNA hybridizations were performed in reverse, i.e., by using the DNAs of $B$. animalis, minimum, and subtile as competitors in 14 reference systems. The data correlate well with those reported in Tables 2 and 3.

Morphology. The cellular morphology of the animalis group exhibits some recognizable traits: the central portions, probably where division into two daughter cells did not go to completion, are often enlarged; branchings can occur at this point to form cross-like elements with branches of nearly the same length (see Fig. 6 of Plate 1); cell extremities are generally enlarged to clavate or spatula-like forms, with occasional rudimentary branchings. Cells of this group display a morphology similar to those of $B$. globosum and $B$. pseudolongum, where short, enlarged, and tapered cells are frequent; however, branching tendencies are not found with the latter two species.
Cells of the shape and size of the two minimum strains (see Plate 2) have not been found in any other bifidobacteria, with the sole exception of $B$. asteroides when grown in deficient media (see Fig. 5 and 6 of Plate 2 of reference 7); they are very minute, short and thin, with tapered ends, and are sometimes irregularly branched. Star-like aggregates of cells, like those characteristic of $B$. asteroides, are absent here. Had it not been for their biochemical characters, the minimum strains could easily be overlooked or mistaken for corynebacteria or anaerobic actinomycetes.

Subtile cells, as the name indicates, are characteristically thinner than those of the usual bifidobacteria; their general shape is reminiscent of $B$. breve Reuter (see Fig. 4 and 5 of Plate 3), but the cells of the latter are often shorter and thicker, swollen and branched (4) (our unpublished observations). Branchings or swellings were not observed in the subtile strains. Because of the few minimum and subtile strains observed, the present morphological descriptions, although generally unusual for bifidobacteria, should be considered as tentative subject to the study of more strains.

TABLE 4. DNA homology relationships between $B$. animalis, the minimum and subtile groups (used as competitors) and species of the genus Bifidobacterium (used as references)

\begin{tabular}{|c|c|c|c|}
\hline \multirow[b]{2}{*}{ Reference strains } & \multicolumn{3}{|c|}{$\begin{array}{l}\text { Percent homology of DNA } \\
\text { from competitor strains }\end{array}$} \\
\hline & $\begin{array}{c}\mathrm{P} 23 \\
\text { (B. ani- } \\
\text { malis) }\end{array}$ & $\begin{array}{l}\mathrm{F} 392 \\
\text { (group } \\
\text { mini- } \\
\text { mum) }\end{array}$ & $\begin{array}{c}\text { F395 } \\
\text { (group } \\
\text { subtile) }\end{array}$ \\
\hline $\begin{array}{l}\text { Bifidobacterium animalis } \\
\text { P23 (ATCC 27536). . }\end{array}$ & 100 & 5 & 8 \\
\hline minimum group F 392 & 8 & 100 & 15 \\
\hline subtile group F395 ... & 10 & 10 & 100 \\
\hline B. bifidum $\mathrm{S} 28 \mathrm{a} \ldots$ & 10 & 5 & 5 \\
\hline B. liberorum $\mathrm{s} 76 \mathrm{e} \ldots$ & 10 & 6 & 5 \\
\hline B. breve $\mathrm{S} 1 \ldots \ldots \ldots$ & 20 & 10 & 14 \\
\hline B. adolescentis E298b & 25 & 4 & 15 \\
\hline B. longum E194b & 8 & 10 & 20 \\
\hline B. catenulatum $\mathrm{B} 669$ & 10 & 25 & 8 \\
\hline B. dentium $\mathrm{B} 764 \ldots$ & 4 & 00 & 00 \\
\hline B. angulatum $\mathrm{B} 677$ & 10 & 20 & 11 \\
\hline B. globosum RU230 & 30 & 5 & 8 \\
\hline B. ruminale RU 326 & 25 & 10 & 18 \\
\hline B. suis SU859 & 20 & 7 & 11 \\
\hline B. asteroides $\mathrm{C} 51 \ldots$ & 5 & 3 & 5 \\
\hline B. indicum $\mathrm{C} 410$ & 00 & 00 & 4 \\
\hline B. coryneforme $\mathrm{C} 215 \ldots$ & 00 & 4 & 00 \\
\hline
\end{tabular}




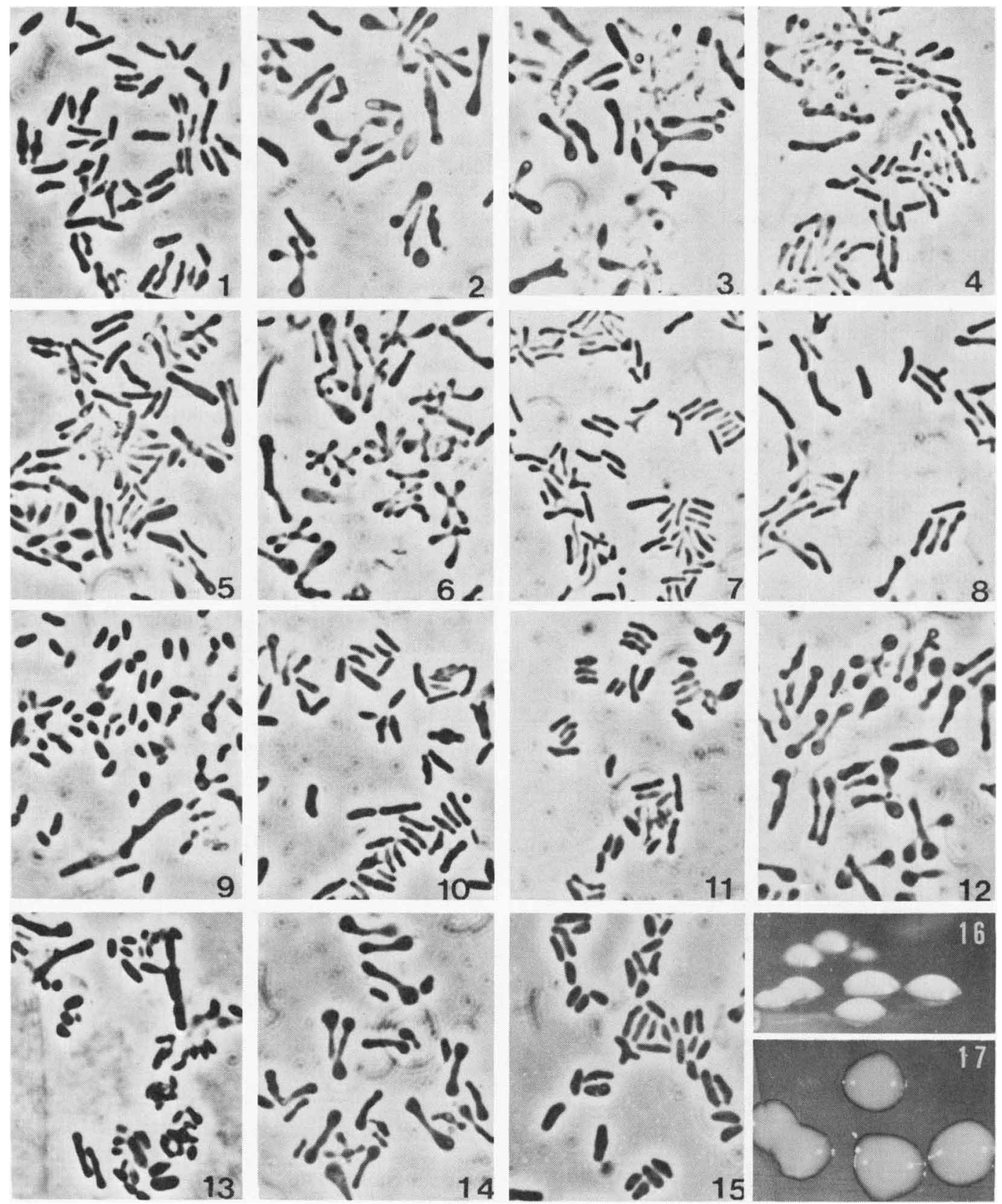

PLATE 1. Morphology of Bifidobacterium animalis (Mitsuoka) comb. nov. Fig. 1 and 2. Strain P23: cells grown anaerobically and under low oxygen tension, respectively, in Trypticase-phytone-yeast extract-glucoseagar medium. Fig. 3 and 4. Strain P16: cells grown in an anaerobic stab and in a broth medium with glucose, respectively. Fig. 5. Cells of strain P17 from an anaerobic stab. Fig. 6. Cells of strain P39 from a 6-day-old broth culture. Fig. 7 to 14. Cells from anaerobic stabs of strains T6, T27, T98, T169, RA13, RA14, F439, and RA20, respectively. Fig. 15. Cells of Mitsuoka strain R101-8 from an anaerobic stab. Phase contrast. X1,500. Fig. 16 and 17. Side and top views, respectively, of surface colonies of the strain P23 on anaerobic slants. $\times 10$. 

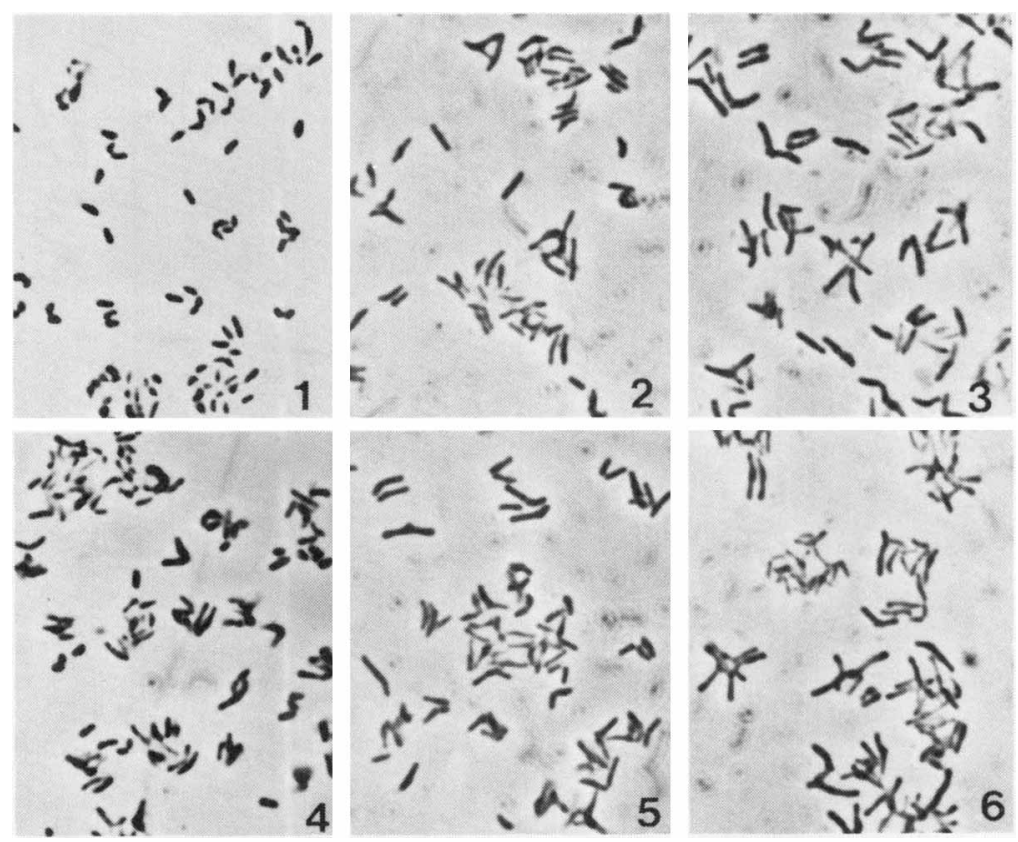

PLATE 2. Morphology of the group minimum. Fig. I to 3. Strain F392: cells from an anaerobic stab (the first transfer after isolation); cells from a 24-h-old broth culture (DNA extraction); and cells from a 6-day-old slant incubated anaerobically, respectively. Fig. 4 to 6. Strain F399: the same as above. Phase contrast. $\times 1,500$.

Physiology: fermentation patterns. Strains of the animalis group fermented arabinose and xylose (Table 5). Strains P16, P17, P23, and P32 were also investigated by W. E. C. Moore (personal communication), who obtained a contradictory negative result with arabinose, a behavior reported for the $B$. infantis-B. liberorum- $B$. lactentis group (9). We cannot explain this discrepancy between our results and Moore's. Pending resolution of this discrepancy, our results suggest that the animalis group can be distinguished from other pentose-fermenting species of Bifidobacterium by the fact that $83 \%$ and $100 \%$ of the animalis strains ferment cellobiose and salicin, respectively, and $100 \%$ of the strains do not ferment gluconate.

The fermentation pattern of the minimum strains is unusual among bifidobacteria. The two strains of the minimum group, like the $B$. thermophilum- $B$. ruminale group and the species from bees, do not ferment lactose; they ferment only glucose, fructose, maltose, dextrin, and, albeit slowly, sucrose and starch. This pattern is evidently quite different from that of $B$. bifidum, the species of the genus with the most restricted fermentation spectrum, i.e., the latter ferments glucose, fructose, lactose, and galactose and is variable in saccharose and melibiose fermentation $(2,3)$.
The subtile strains also did not ferment lactose, arabinose, or xylose, but they differed from lactose-negative species such as $B$. indicum and $B$. ruminale in that the subtile strains fermented sorbitol and gluconate.

Other physiological and biochemical characteristics. The physiological and biochemical characteristics of $B$. animalis and of the minimum group are in line with those of most bifidobacteria (see below). The subtile strains have an optimum growth temperature near 35 $\mathrm{C}$ and a maximum not higher than $40 \mathrm{C}$; these temperature relationships are not shared by any known species of Bifidobacterium. Furthermore, these strains (subtile group) are unique bifidobacteria in that their cell-free extracts possess both "animal" and "human" electrophoretic types of fructose-6-phosphate phosphoketolase (F6PPK) (6).

The results of this study show conclusively that the 22 strains of bifidobacteria we isolated from the feces of chickens, rats, and rabbits, and from sewage, are identical to $B$. longum subsp. animalis biotype $a$ strain R 101-8 isolated by Mistuoka from the feces of rat because they displayed complete DNA relatedness to this strain and had the same phenotypic characteristics. However, these bifidobacteria cannot be included in a subspecies of $B$. longum Reuter 


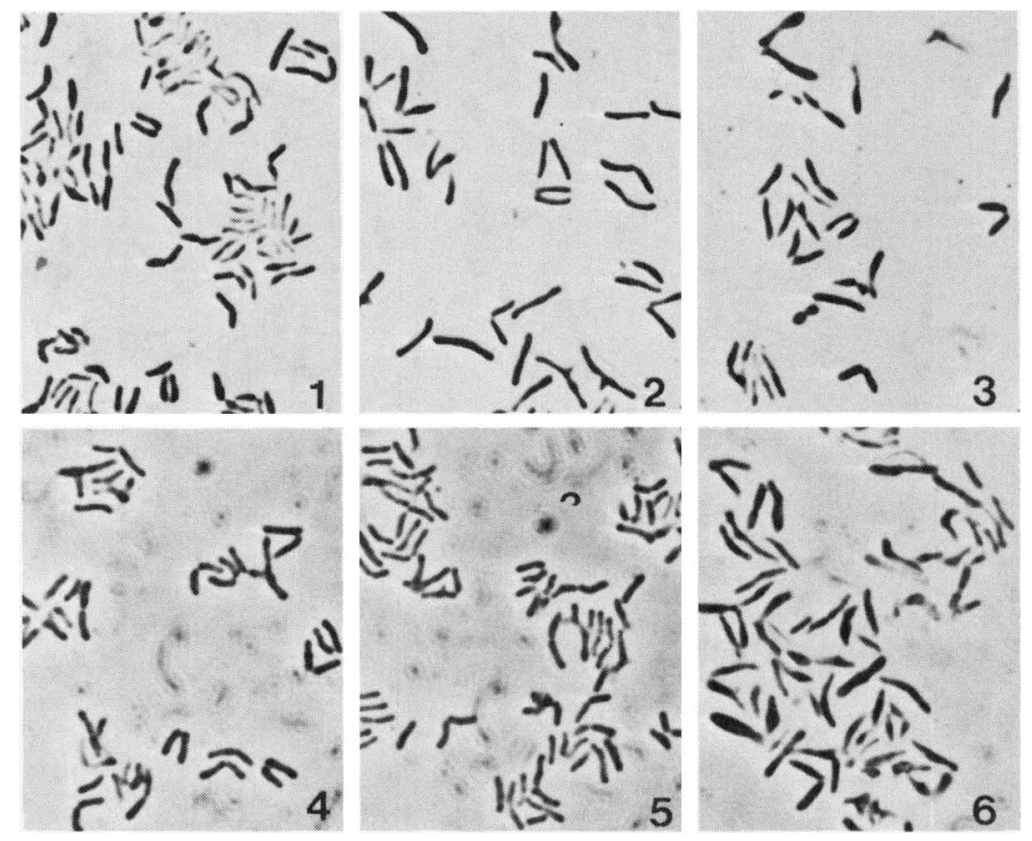

PLATE 3. Morphology of the group subtile. Fig. 1. Cells of strain F395 from a 24-h-old anaerobic stab. Fig. 2 and 3. Cells of strains F394 and F396, respectively, as above. Fig. 4 and 5. Cells of strain F395 from 6-day-old broth cultures containing glucose and gluconate, respectively. Fig. 6. Cells of strain F396 from a 24-h-old broth culture (DNA extraction). Phase contrast. $\times 1,500$.

because they do not share with the type strain of this species any common DNA base sequences, as revealed by levels of DNA homology of $<10 \%$. Therefore, we propose the creation of the new species Bifidobacterium animalis (Mitsuoka) comb. nov. The minimum and subtile groups are not proposed as new species because of the small number of strains studied.

The main characters of this new species are are summarized as follows.

Bifidobacterium animalis (Mitsuoka) comb. nov. ( $B$. longum Reuter subsp. animalis Mitsuoka biotype $a$ ).

Cell characteristics. Gram-positive, nonmotile, nonsporeforming short rods ( 2 to $4 \mu \mathrm{m}$ ) with the central area generally slightly enlarged; in longer cells, distal portions may be clavate or spatula-like. Branchings can occur to form cross-like aggregates of four cells distally inflated. (Plate 1, Fig. 1-15)

Surface colonies. Smooth, convex, entire edges, cream to white, glistening and soft. (Plate 1, Fig. 16 and 17)

Relationships to oxygen and $\mathrm{CO}_{2}$. Anaerobic; $\mathrm{CO}_{2}$ has no effect upon oxygen sensitivity and upon anaerobic growth. No growth in slants incubated in air or in air enriched with carbon dioxide.

Temperature relationships. Optimum, 39 to $41 \mathrm{C}$; minimum, about $25 \mathrm{C}$; maximum, 44.5 to $45 \mathrm{C}$; no growth at $24 \mathrm{C}$ or $46 \mathrm{C}$.

pH relationships. Initial optimum, 6.4 to 7.0 ; retarded growth at 6.0 or 7.4 ; no grow th at 5.0 or 8.0 .

End products from glucose. Lactic and acetic acids are produced in a molar ratio of 1:3.6 \pm 0.3 in Trypticase-phytone-yeast extract medium. Isomeric type of lactic acid produced: $\mathrm{L}(+)$. Propionic and butyric acids are not produced.

Fermentation pattern. The fermentation pattern is given in Table 5. The fermentation of cellobiose and salicin is not observed in the other species of Bifidobacterium which ferment pentoses but not gluconate.

Enzymology. Fructose-1,6-diphosphate aldolase: approximately 3 to $4 \mathrm{mU}$ of specific activity; glucose-6-phosphate (G6P) dehydrogenase (oxidized nicotinamide adenine dinucleotide phosphate [NADP $\left.{ }^{+}\right]$dependent): demonstrable (nearly $2 \mathrm{mU}$ of specific activity); 6-phosphogluconate (6PG) dehydrogenase (NADP ${ }^{+}$dependent): some 40 to $50 \mathrm{mU}$ of 
TABLE 5. Fermentation patterns of Bifidobacterium animalis and the minimum and subtile groups ${ }^{a}$

\begin{tabular}{|c|c|c|c|c|}
\hline \multirow[b]{2}{*}{ Compound } & \multicolumn{2}{|c|}{ B. animalis } & \multirow{2}{*}{$\begin{array}{l}\text { minimum } \\
\text { group } \\
(2 \text { strains })\end{array}$} & \multirow{2}{*}{$\begin{array}{c}\text { subtile } \\
\text { group } \\
\text { (5 strains) }\end{array}$} \\
\hline & 23 strains & $\begin{array}{c}\text { Type strain } \\
\left(\text { ATCC 25527) }^{b}\right.\end{array}$ & & \\
\hline L-Arabinose $\ldots \ldots$ & $+{ }^{c}(23 / 23)$ & + & - & $-(5 / 5)$ \\
\hline D-Xylose $\ldots \ldots$ & $+(23 / 23)$ & + & - & $-(5 / 5)$ \\
\hline D-Ribose $\ldots \ldots$ & $+(23 / 23)$ & + & - & $+(4 / 5)^{j}$ \\
\hline D-Mannose $\ldots \ldots$ & $-(18 / 23)^{d}$ & - & - & $-(5 / 5)$ \\
\hline Galactose .. & $+(23 / 23)$ & + & - & $+(5 / 5)$ \\
\hline Sucrose ....... & $+(23 / 23)$ & + & + & $+(5 / 5)$ \\
\hline D-Cellobiose $\ldots$ & $+(19 / 23)^{e}$ & - & - & $-(4 / 5)^{k}$ \\
\hline Lactose . . . . . . & $+(23 / 23)$ & + & - & $-(5 / 5)$ \\
\hline D-Trehalose .... & $-(17 / 23)^{f}$ & - & - & $-(4 / 5) k$ \\
\hline Melibiose $\ldots \ldots$ & $+(22 / 23)^{g}$ & + & - & $+(5 / 5)$ \\
\hline Raffinose ..... & $+(23 / 23)$ & + & - & $+(5 / 5)$ \\
\hline Melezitose .... & $-(14 / 23)^{h}$ & - & - & $+(5 / 5)$ \\
\hline Dextrin ....... & $\left.+(22 / 23)^{i}\right\}$ & \pm & + & $+(5 / 5)$ \\
\hline Starch .. & $\left.+(22 / 23)^{\prime}\right\}$ & \pm & + & $+(5 / 5)$ \\
\hline Inulin & $-(23 / 23)$ & - & - & $-(4 / 5)^{k}$ \\
\hline Sorbitol & $-(23 / 23)$ & - & - & $+(5 / 5)$ \\
\hline Salicin .... & $+(23 / 23)$ & + & - & $-(3 / 5)^{l}$ \\
\hline Gluconate . & $-(23 / 23)$ & - & - & $+(5 / 5)$ \\
\hline
\end{tabular}

${ }^{a}$ All strains ferment glucose, fructose, and maltose; none ferments mannitol, glycerol, rhamnose, or lactate.

$b$ The fermentation pattern of the type strain corresponds to that given by Mitsuoka (2) for $B$. longum subsp. animalis.

$c$ Symbols: + , fermented; - , not fermented; \pm , very delayed reaction.

${ }^{d} \mathrm{P} 26, \mathrm{~T} 6, \mathrm{~T} 27, \mathrm{~T} 160$, and RA23 were positive.

$e$ P45, T98, RA23, and R101-8 were negative.

$f \mathrm{P} 17, \mathrm{P} 26, \mathrm{P} 32, \mathrm{P} 39, \mathrm{~T} 27$, and $\mathrm{T} 160$ were positive.

g RA12 was negative.

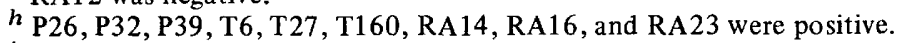

$i$ Only strain R101-8 ferments these sugars very slowly.

${ }^{j} \mathrm{~F} 395$ was negative.

${ }^{k}$ Only strain F396 ferments these sugars.

${ }^{l} \mathrm{~F} 395$ and $\mathrm{F} 396$ were positive.

specific activity; electrophoretic type of F6PPK: "animal."

Biochemical reactions. Catalase or pseudocatalase (hemin) not produced; nitrate not reduced; indole not produced; acetylmethylcarbinol produced; gelatin not liquefied; skim milk acidified and coagulated; ammonia not produced from urea or arginine.

G + C content of DNA. $60.1 \pm 0.3 \mathrm{~mol} \%$ $\left(T_{m}\right)$.

DNA homology relationships. Little or no relationship to all other known species of the genus.

Sources. The feces of chickens, rats, and rabbits, and sewage.

Type strain. R101-8 (=ATCC 25527); designated as the type strain by Mitsuoka (2), who isolated it from the feces of a rat.
Distinctive characters of the minimum and subtile strains are summarized as follows.

1. Minimum group.

Cell characteristics. Very small cells, 0.3 by 1.3 to $1.5 \mu \mathrm{m}$, with tapered ends and sometimes irregularly branched. Star-like aggregates, like those in $B$. asteroides Scardovi and Trovatelli, are absent.

End products from glucose. Lactic and acetic acids are produced in a molar ratio of $1: 3.3$. $\mathrm{L}++$ lactic acid is formed. Propionic and butyric acids are not produced.

Fermentation pattern. The fermentation pattern is given in Table 5.

Enzymology. Only 6PG dehydrogenase is measurable; the "animal" electrophoretic type of F6PPK is produced.

DNA homology relationships. Unrelated to 
any other species of Bifidobacterium from man or other animals, including bees.

Source. Sewage.

Reference strain. F392 (=ATCC 27538).

2. Subtile group.

Cell characteristics. Slender rods, 0.5 by 2 to $3 \mu \mathrm{m}$, with rounded or tapered ends, sometimes curves; branchings are not evident.

Temperature relationships. Optimum, 34 to $35.5 \mathrm{C}$; maximum, near $40 \mathrm{C}$; minimum, $22 \mathrm{C}$.

Fermentation pattern. The fermentation pattern is given in Table 5 .

Enzymology. G6P dehydrogenase activity (both oxidized nicotinamide adenine dinucleotide and $\mathrm{NADP}^{+}$dependent) is rather evident (some 10 to $15 \mathrm{mU}$ of specific activity in strain F395); both "animal" and "human" electrophoretic types of F6PPK are present.

DNA homology relationships. Unrelated to any known species of the genus Bifidobacterium.

Source. Sewage.

Reference strain. F395 (=ATCC 27537).

\section{ACKNOWLEDGMENTS}

We are grateful to W. E. C. Moore, Virginia Polytechnic Institute and State University, Anaerobe Laboratory, Blacksburg, Va., for invaluable information concerning the phenotypic characters of a large number of our isolates.

The technical assistance of $\mathrm{N}$. Vincenzi is gratefully acknowledged.

This investigation was supported by a research grant from the Consiglio Nazionale delle Ricerche, Roma.

\section{REPRINT REQUESTS}

Address reprint requests to: Dr. V. Scardovi, Istituto di Microbiologia Agraria, Università di Bologna, Bologna, Italy.

\section{LITERATURE CITED}

1. Matteuzzi, D., F. Crociani, G. Zani, and L. D. Trovatelli. 1971. Bifidobacterium suis n. sp.: a new species of the genus Bifidobacterium isolated from pig feces. Z. Allg. Mikrobiol. 11:387-395.

2. Mitsuoka, T. 1969. Vergleichende Untersuchungen über die Bifidobakterien aus dem Verdauungstrakt von Menschen und Tieren. Zentralbl. Bakteriol. Parasitenk. Infektionskr. Hyg. Abt. I Orig. 210:52-64

3. Reuter, G. 1963-64. Vergleichende Untersuchungen über die Bifidus-Flora im Sauglings- und Erwachsenenstuhl. Zentralbl. Bakteriol. Parasitenk. Infektionskr. Hyg. Abt. I Orig. 191:486-507.

4. Reuter, G. 1971. Designation of type strains for Bifidobacterium species. Int. J. Syst. Bacteriol. 21:273-275.

5. Scardovi, V., and F. Crociani. 1974. Bifidobacterium catenulatum, $B$. dentium, and $B$. angulatum: three new species and their deoxyribonucleic acid homology relationships. Int. J. Syst. Bacteriol. 24:6-20.

6. Scardovi, V., B. Sgorbati, and G. Zani. 1971 Starch gel electrophoresis of fructose-6-phosphate phosphoketolase in the genus Bifidobacterium. J. Bacteriol. 106: 1036-1039.

7. Scardovi, V., and L. D. Trovatelli. 1969. New species of bifid bacteria from Apis mellifica $\mathbf{L}$. and A pis indica $\mathrm{F}$. A contribution to the taxonomy and biochemistry of the genus Bifidobacterium. Zentralbl. Bakteriol. Parasitenk. Infektionskr. Hyg. Abt. II 123:64-88.

8. Scardovi, V., L. D. Trovatelli, F. Crociani, and B. Sgorbati. 1969. Bifidobacteria in bovine rumen. New species of the genus Bifidobacterium: $B$. globosum n. sp. and B. ruminale $\mathrm{n}$. sp. Arch. Mikrobiol. 68:278-294.

9. Scardovi, V., L. D. Trovatelli, G. Zani, F. Crociani, and D. Matteuzzi. 1971. Deoxyribonucleic acid homology relationships among species of the genus Bifidobacterium. Int. J. Syst. Bacteriol. 21:276-294. 